\title{
Liberal Citizenship and the Hermeneutics of Public Dialogue: A Rawlsian Perspective
}

Joseph Rivera

Dublin City University

\section{Abstract}

Focusing on the topic of public dialogue between religiously theistic, quasireligious, atheistic, and non-religious citizens in a liberal democracy, this paper develops a practical strategy of dialogue in the wake of Rawls' Political Liberalism (1993). To set the stage for a rereading of Rawls, the chief points of liberal citizenship are outlined in critical dialogue with recent literature that urges citizens to abandon liberalism. While metaphysics, religious norms, and moral visions of the good are not bracketed by liberal regimes, it is true that liberal states nonetheless attempt to remain neutral in matters of religion and worship. This may yield many worldviews incommensurable with each other. Liberalism, then, as a political order, involves a pluralism of worldviews, some religious and some not. A hermeneutics of public dialogue can enable citizens to be reconciled with, rather than escape, the pluralism born of liberalism. I suggest the point of departure for such a hermeneutic lies in the vocabulary of Rawlsian "overlapping consensus." Reconsidered in this light, overlapping consensus can open up the prospect of dialogue among citizenry in the public square in a manner that facilitates agreement and cooperation. This is due to the fact that overlapping consensus contrasts with the idea that when one converges on a policy, one must always do so for the same reason or theoretical justification. The paper concludes with the structure of a four-way dialogue that may result from the application of this hermeneutic.

\section{Keywords}

hermeneutics; liberalism; political constructivism; public dialogue; Rawls

Within itself the political conception does without the concept of truth... Once we accept the fact that reasonable pluralism is a permanent condition of public culture under free institutions. Holding a political conception as true, and for that reason alone the one suitable basis of public reason, is exclusive, even sectarian, and so like to foster political division. - John Rawls (1995, 94, 129).

\footnotetext{
* Joseph Rivera, Dublin City University, All Hallows Campus, Grace Park Road, Dublin 9, Ireland; joseph.rivera@dcu.ie. ORCID 0000-0001-8650-7918.
} 


\section{Pluralism Today: A Fait Accompli}

Because it obeys the law of neutrality in matters of religious and cultural values, the liberal order opens up an array of choices a citizen may make in the construction of his or her personal identity, ranging from religion and gender to ethnicity and language (among other features). The liberal order does not enforce pluralism, but it does, one could argue, indirectly promote a culture of pluralism. While the law of liberal neutrality corresponds to the fact that the liberal state cannot exercise preferential treatment on behalf of one religion over another (or over those who embrace no religion), such neutrality is not true for society at large, and by implication, for political parties. ${ }^{1}$ Liberal regimes, therefore, do not place limits on the political and public manifestations of pluralism. There are Christian citizens, Jewish citizens, Muslim citizens, atheist citizens, and so forth, just as there are Christian political platforms, green political platforms, Hindu political platforms, etc.

It would appear that, in spite of what one would expect, the culture of pluralism does not always open out onto a spectrum of political perspectives in western democratic culture. Why this is so has become increasingly difficult to diagnose. What is clear is that the ballot box in increasingly reduced to a binary opposition. Sometimes (though not always) described in both American and European contexts in the vocabulary "left" versus "right," or "liberal" versus "communitarian," these two dominant paradigms of citizenship tend to offer a stark either/or framework. ${ }^{2}$ Usually, the left is cast in a secular, multicultural frame of mind and the right a religious, nationalist one; it is thus no surprise that proponents of each paradigm are embattled in partisan rivalry. So contemptuous of each other in recent years are the two "parties" or "cultures" (left versus right) that statistics on the subject matter are plentiful: mutual animosity between them has only escalated in recent years.

For example, a 2016 Pew Research Study indicates that for the first time since 1992 majorities in both the Democratic and Republican parties express not just unfavorable but very unfavorable views of the other party. More to the point, of Republicans say that the Democratic Party makes them feel "afraid" (49\%) and "angry" (46\%) and most of all, "frustrated" (57\%); Democrats rank

$1 \mathrm{I}$ am influenced here by analytical distinctions made about the manifestation of the secular in Ingolf Dalferth, (2010).

2 Certainly, the vocabulary of "right" versus "left" is too binary to capture the complexity of political platforms on offer in Europe especially, but equally so in America. However, the vocabulary is regularly employed by political theorists who refer to and diagnose both American and European political rivalry. For the European context, in which the language of communitarian is used explicitly, see for example, Jürgen Habermas (2012); Pierre Manent (2015); Kathleen R. McNamara (2015). Peter Deneen's volume, which I shall engage below, will suffice for the American context. 
even higher on the scale of the threefold emotional register of partisanship, at 55\%, 47\%, and 58\%, respectively (http://www.people-press.org/2016/06/22/ partisanship-and-political-animosity-in-2016). Another recent study of political culture in America shows an amazing new consequence of political animosity. In 1960, Americans were asked how they would feel if their child married a partner who identified with another political party. The findings at that point were marginal, in that $4 \%$ of Democrats and $5 \%$ noted they would be "displeased." Updated in 2010, the same statistical report shows that $33 \%$ of Democrats and $49 \%$ of Republicans would be "somewhat or very unhappy" at the prospect of intermarriage (Shanto, et al. 2012). Political identity, in other words, invokes not a discrete political platform, but a way of life. As we shall see in the concluding remarks, however, personal identity bears within it several properties and characteristics, and therefore offers opportunities for overlap that have been hitherto overlooked by identity politics. The concept of overlapping consensus can help citizens rediscover points of overlap we share with each other. Polarization, political or otherwise, can become deflated. Yet, political rivalry, statistics apart, does bring about real consequences in public life.

For example, Supreme Court justices, who are to aspire to impartiality, do not escape the centrifugal force of political polarization. The American Supreme Court, for example, remains divided by ideology. It ratifies a decision according to purely "constructionist" readings of the constitution (conservative) or living interpretations of the constitution (liberal). ${ }^{3}$ The case in point was the 2000 Supreme Court case over Bush v. Gore (2000), the recount in Florida, whereby the five conservative justices clearly voted according to partisan prejudice. ${ }^{4}$ Democracies can "die" (as one recent volume proclaims) at the hands of vicious partisanship and escalating animosity. Recent casualties are found in countries like Peru and Venezuela, and more recently, in Hungary and Poland. Brazil just elected a far-right candidate in Jair Bolsonaro. Trumpism for the moment achieved victory in the United States.

We may ask of the social and political fallout of such a socio-cultural divide. What does increasing mutual political animosity ultimately mean, not only for American citizenship but also for Western liberalism broadly? Is the liberal order as a whole under threat of extinction?

3 For more on the bipolarity of the American Supreme Court politics, see Ronald Dworkin (1986, 358).

4 For more on the partisan politics of the Gore v. Bush Supreme Court Case, see William Connolly (2005, 132-35).

5 For a fascinating portrayal of the many failed democracies across the globe, see Steven Levitsky and Daniel Ziblatt (2018). 
Is the liberal order culpable or at fault here for such large-scale political disequilibrium on the one hand, and, on the other, for banana republics and failed states? Given that liberalism invites the individual citizen to pursue whatever ends she likes, it follows that a plurality of worldviews, religions, visions of the good, and cultural norms (often incommensurable with each other) necessarily arises. Disagreement about which virtues are best (accepting immigrants versus protecting borders and national sovereignty, for example) yields to political standoffs, brinkmanship and, sometimes, economic consequences like a government shutdown or, finally, a full-scale political insurgency of anti-democratic parties. Recent scholarly volumes on the current climate describe its pathos as a politics of "fear" or "horror," precisely because anxiety, suspicion, and intolerance have beleaguered citizens on both sides of the divide, showing we are unable to cope with pluralism, and specifically, religious and ethnic differences (Bivins 2008; Nussbaum 2013).

I should like to urge at this juncture that liberal citizenship, if it is both to survive and flourish, signals the need for a clear and practical hermenuetic of "public dialogue." One is not born a liberal citizen but must "become" one; to overcome the parochial or local identity with which we have been endowed is to engage in an intentional deflationary strategy of public dialogue. The following paragraphs briefly address this strategy mediated by John Rawl's "idea of overlapping consensus" as it is articulated in his late work, Political Liberalism (1993).

Central to the strategy of overlapping consensus is the twofold problem of pluralism and liberalism. How do the two interrelate and mutually reinforce each other? Pluralism, Rawls will claim over and again, is a "reality" of liberal society, a brute fait accompli with which we must become reconciled. It will not recede in the face of secularism. Nor will it fade in the wake of the return of religion. Liberal society is as diffuse as ever, in spite of the increasing animus left and right feel for each other. Whether pluralism occasions a moral vision to be protected (known as value pluralism), I shall not address here. The relevant point for the present essay is that pluralism, however it is to be valued, forms irrecusably the overarching horizon of publicness, such that it is an empirical "given," a state of affairs born of late-modern liberal policies precisely because such regimes protect autonomy. Citizens never may take for granted that their interlocutor identifies as a Christian, as may have been the case a few generations ago in the west. Precisely because the government puts in place measures assuring all citizens adequate means to make effective use of the freedom of religion and freedom of conscience, the "inevitable outcome" of such liberty is pluralism. The conviction of Rawls' observation that the 
most "intractable struggles" a body of citizens may endure are fought for the sake of the "highest things" such as religious truth and moral conceptions of the good. It is indeed remarkable that a liberal society should hang together at all in light of the fact that we remain deeply divided by religious and moral worldviews (Rawls 1995, 4). Liberal democracies, fragile at their foundation, therefore, cannot afford to accommodate citizens who either have no truck with or seek to extinguish pluralism.

Because autonomy is protected, reasonable disagreement over political and social issues shall arise in liberal states. This has become acutely obvious in social matters of great ethical importance like bioethics, artificial intelligence, abortion, gun control, war, etc. Liberalism does not commit itself to enforcing one particular worldview or comprehensive doctrine of the good (even that of pluralism): the freedom of religion and freedom of conscience are products of free institutions.

Following from these basic liberties, a question ensues. Does pluralism not only yield disagreement but also political animosity? Certainly, both do emerge on the stage of public life, but animosity itself, a toxic mood, does not of necessity stem from pluralism. How can we manage animosity, keeping it at bay? A properly Rawlsian interpretation of liberalism may assist, in part, in the task of minimizing division and bitter rivalry. For a fuller account of the liberalism's relationship to political polarization, we turn first to a recent misguided account of the structure and logic of liberalism, followed by a more detailed look at Rawls' work.

\section{Is Liberalism an Ideology of the Subject?}

Rawls elucidates the basic shape of liberalism in his later Political Liberalism: its political conception of justice because it is purely political, does not trade on a comprehensive moral scheme of right and wrong. Hence, it never may establish or legally sanction the practice of a particular theological confession or moral tradition or comprehensive doctrine (whether that is Christianity, Islam, atheism, etc.). Neither may it legally prohibit it. The liberal order governs in a manner that could be described as pragmatic because it does not justify its rule of law on theological or metaphysical grounds of any kind. It delegates the responsibility of moral practice and truth claims to individual choice, and therefore, it enables individuals to adopt whatever religion or moral quest they should like to pursue and enjoy. Political constructivism of the liberal kind does not invoke metaphysical "truth" as its ground, but rather specifies only the minimum of moral norms that need to be legally in place for public reason to guide citizens in the liberal way: to cooperate with each other 
as free and equal citizens (more on political constructivism in the subsequent section). This kind of liberalism, sometimes called simply "political liberalism" or "liberal egalitarianism," is not what critics of liberalism actually have in mind when they condemn or denounce "liberalism" as a decadent ideology of moral relativism that arises as an effect from an ahistorical procedural theory of justice out of touch with reality.

For example, Patrick Deneen's widely read Why Liberalism Failed has blamed liberalism for the visible signs of internal instability displayed in numerous democracies across the West. His point here hinges chiefly on a definition of liberalism as such. He believes it to be an ideology, complete with a definition of the person as an abstract atom, an economic plan that indulges capitalism's greed, and finally, an educational roadmap that focuses on the sciences at the expense of the liberal arts. Yet what I think he targets is but a kind of secular communitarianism, sometimes also called perfectionist liberalism (Nussbaum 2011).

Deneen's scathing critique of political liberalism, if at once exaggerated and calculated, remains valuable because it formulates a standard Christian communitarian protest: liberalism relies on a certain, specific understanding of the subject, namely, that subjects like you and me are autonomous monads whose essence transcend time, place, tradition, and culture. The forlorn story told in the pages of Why Liberalism Failed evokes a quixotic past, when Ancient Greek concepts of the polis were accompanied by Christian virtue. This synthesis of Greek politics and Christian community bore witness to an alternative anthropology, to an individual always already in relationship with a comprehensive natural order of goods and ends. Redolent of so many other bromides about liberalism's failures that abound in the literature, Deneen's book suggests that modernity sought to erase that teleological structure embedded in the human condition.

From what novel discourse or twist in the plot of western history did modernity spring? Liberalism's infant stages emerged from the early liberal order's discourse of "state of nature." An anthropological "bare form" that Locke and Rousseau (who opens the Social Contract with the exclamation, "man was born free, and everywhere he is in chains!") say we each possess and have in common, the human condition summons forth a clear two-tiered design (Rousseau 1999, 45). (i) First, the underlying naked (and innocent) subject whose inborn freedom has been tainted by culture. After entrance into society, the community foists on top of each of us a second tier, (ii) a

6 For more on the resonances between political liberalism and political egalitarianism, see Cécile Laborde (2017, Part I). 
"layer" or "tier" of cultural convention that enchains and enfeebles our pure state of nature, primarily by demanding that each of us follows moral norms, cultural conventions, religious codes, legal restraints, etc. (Deneen 2018, 34-42). Liberalism appears to prioritize the first tier (i) over and above its derivative, tier two (ii). Deneen argues liberalism's abstract subject, expressed in the idiom of the "state of nature," liberates all citizens from "particular duties, obligations, debts, and relationships," not least from "embedded cultures, traditions, places, and relationships," which enables liberalism to "homogenize" the world according to the unvarnished image of the state of nature (Deneen 2018, 16-7).

How does liberalism denude or strip us of the sense of place, home, and history, as Deneen would have us believe it does? How does liberalism render void our embedded and relational anthropology that stems from tier two (ii)? As if it exercised an invisible agency over us, the liberal imagination prohibits such rootedness in particular traditions. Instead, as if by way of widespread compulsion, the liberal tradition, enforced by a liberal state, promotes "hedonic titillation, visceral crudeness, and distraction, all oriented toward promoting consumption, appetite, and detachment" (Deneen, 2018, 39). Liberalism "eviscerates" (by defunding) the liberal arts education, the deep source of wisdom that affords us the privileged opportunity to learn that there is no such thing as a state of nature or an underlying "autonomous agent" lurking as an unencumbered substructure on which the civil discourse of selfrestraint, virtue, and modesty can develop.

Such an uncompromisingly negative view of liberalism and the liberal state does not consider the agency or legal mechanics of such cultural deracination. Why is the state the only form of organization available to liberal citizens? Why must we give up religion or community or culture? Who possess the power to dissolves these ties? If we are "shorn" or purged of basic sources of community and belonging, how is this achieved in practice? What is the proximate agent of dissolution of cultural identity? Do all demographics undergo such total and complete deracination, or only those living in dense urban areas? Is a local culture erased by the liberal state, and if so, by what mechanism does it accomplish this homogenization and fascist repression of its citizenry's cultural, religious, and linguistic preferences? None of these questions are addressed by Deneen.

The only way forward, for Deneen, is "liberation from liberalism itself" (Deneen 2018 18). Of course, he does not thematize or propose a politics of nostalgia. To look backward would be to replace liberalism with monarchy or any other kind of authoritarian form of governance, ancient empire or medieval Christendom. 
He would like to repristinate an original economy of place and tradition so that each citizen's thick moral and familial history does not have to submit to the denuding power of liberalism's anthropology, its state of nature. Citizenship for Deneen's anti-liberal inclinations should draw on basic mediating institutions, local, participatory, small-scale institutions like we see in the medieval or ancient world (trade organizations, grassroots movements, guilds, fraternities, local associations, etc.) (Deneen 2018, chapter 8).

One can appreciate the emphasis on local goods, languages, norms, etc. But is the liberal state responsible for giving the citizenry such mediating forms of community? Is the liberal state supposed to craft a moral compass or a thick familial lifeworld for each citizen, with a teleological narrative passed down and transmitted from generation to generation, through the ages? This kind of communitarianism, which motivates Deneen's Why Liberalism Failed, veers toward an anti-liberal stance. From a communitarian perspective, churches exemplify institutions that are well suited to be the moral teachers of their members, as well as public witnesses to that truth. Churches speak in a public voice that is articulated as one voice among others in the public square. ${ }^{7}$ The state does not serve this moral purpose, in spite of Deneen's demonstrative suggestion that it should cultivate the moral norms and theological virtues of Christianity for the whole citizenry.

Deneen's analysis, representative of a surrogate of many critics of liberalism, does not actually carry out an analysis of the liberalism as many theorists or constitutional documents envisage it. How may we characterize liberalism, then? We turn to the most influential contemporary theorist of liberalism, John Rawls. Here, we see a sober, responsible, and ultimately, "embedded" framework of the liberal tradition, what he calls "political constructivism."

\section{Rawlsian Political Constructivism}

Once we briefly discuss and outline the political liberalism as it is conceived by liberal theorist John Rawls, in this section, we shall be in position to offer a sketch of a framework for public dialogue. Liberalism (and Rawls is its major contemporary theorist) can promote solidarity and commonality for citizens who live by and act according to "thick" or comprehensive moral commitments, cultural imaginations, and metaphysical/rational entitlements.

I am not arguing that this interpretation of liberalism is the only permissible one that might be taken as a point of departure for the issue of solidarity in the give-and-take of public dialogue. The point I wish to make is rather that

7 I am influenced by the wisdom of Merold Westphal on this point $(2009,132)$. 

Liberal Citizenship and the Hermeneutics of Public Dialogue: A Rawlsian Perspective it is inaccurate to portray liberalism as a product of crude Enlightenment prejudice against religion, as if liberalism's moral norms reflect a disembodied antireligious agenda. Political liberalism, as Rawls notes, can be (though not necessarily is) accommodated by the world's major religions, from Christians to Muslims to Hindus, not least by atheists and religious ones (Rawls 1995, 438). As a political polity that governs public life, liberalism does not as a rule, as Alessandro Ferrara claims, devolve into a form of reactionary tyranny in the face of hyperpluralism (Ferrara 2013). Liberalism's vision of liberty enables each citizen to negotiate among moral norms, which does not entail the need for the state "to "domesticate difference" (Ferrara 2013, 89). It instead manages difference, not so that it may domesticate it, but liberate it. ${ }^{8}$ What of Rawls' conception of the "original position?" Would it not categorically deny difference (with the veil of ignorance) in favor of an abstract subject? Does it not grow out of Enlightenment aspirations to transcend time and space, and thus, escape the embodied expressions of personal identity?

Liberalism, it should be acknowledged first, because it liberates difference, cannot proceed on the assumption that all public voices are commensurable. Liberalism's conception of pluralism involves the recognition that there are no rules which tell us how rational agreement can be reached on what would resolve an issue on every point where statements seem to conflict. Rawls remains consistent in the claim that if reasonable pluralism imagines a picture of society in which multiple incommensurable moral judgments and religious perspectives coexist, it cannot be taken for granted that the liberal state can attain an objective position or "disinterested perch" that enables it to find common ground on the basis of a single political rule or moral norm. When he asks citizens, then, to "simulate being in the original position," he invites them to perform an imaginative act of abstraction, for the sake of unity with the other. He states that it "in the original position, our reasoning no more commits us to a particular metaphysical doctrine about the nature of the self than our acting a part in a play, say of Macbeth or Lady Macbeth" (Rawls 1995, 27). Rather than seek the timeless and stable grandeur of a timeless "metaphysical" conception of neutral justice, the original position opens up the possibility of self-critical solidarity with the other.

The ultimate aim of this political performance, of "assuming the role" of the original position, is that, so far as she can, a citizen is to place her contingencies and prejudices, as well as privileges, behind a veil of ignorance. While Rawls

\footnotetext{
8 Other contemporary theorists of liberalism would basically concur with Rawlsian political constructivism. See, for example, two influential accounts: Pierre Manent (1996, 60-1) and Dworkin (2008, 9-12).
} 
may say a "thick veil" remains a viable option, I would not agree complete ignorance is achievable (I shall not devote space to the important difference between thick versus thin veils). For now, it suffices to say that the original position is finally a "test of reflective equilibrium" between "you and me," that is, between two enfleshed, historical subjects who have real commitments and who genuinely embody "firm convictions of political justice" (Rawls 1995, 28). So, the work of abstraction set into operation by the original position is not gratuitous: it is not abstraction for the sake of abstraction. It is instead an intentional manner of occupying a site of difficult dialogue only after shared understandings of morality, religion, public policy, and political justice have broken down. When prejudice and privilege configure the public exchange of reasons, then we should be prepared to overcome that conflict by stepping back from our prejudices and privileges, in an imaginative act of abstraction. While it is not perfect, the original position motivates us to ascend to the necessary level of abstraction, where we may approach a "clear and uncluttered" of our solidarity that can help us overcome the roots of conflict and rivalry (Rawls 1995, 47 and 72).

The chief point of the exercise of the imaginative labor that makes possible the simulation of the original position is the following: to get conscious of the fact that no "religious or philosophical system" can ground or serve as a justifying principle for public reason. Hence, as a subset of practical reason, liberal democracy consists of a practice that maximizes individual freedom rather than a principle that protects a certain moral norm (Rawls 1995, 109). This interpretation of political liberalism, to be clear, sets it apart from comprehensive or perfectionist liberalism, which decides its principles in accord with a particular definition of objective truth. In contrast, Rawls advances political liberalism, a form of governance that asks how political order can be established independently of a tie to a set of universal moral values, without implying no such universal moral norm may exist for many citizens. That is, "it neither asserts nor denies an independent order of values," and this is because "political constructivism says an objective moral order goes beyond the bounds of a political conception of justice so far as possible to be acceptable to all reasonable comprehensive accounts" (Rawls 1995, 11314). Within the broader context of social cooperation among citizens, the Rawlsian political concept of justice retains imprecision, but therein lies its strength. In spite of the attempt of some liberal theorists to secure it as a neutral, abstract doctrine of justice, political liberalism's criteria of justice are drawn from the citizenry's pluralistic makeup (not from an Enlightenment principle of atheism that seeks to privatize religion). Hence, constructivism 
"is only about political values, not moral values generally" (Rawls 1995, 125). Moral values are values left up to individual discretion, as long as such values do not undermine a fair system of cooperation between free and equal citizens (Rawls 1995, 126).

To abandon the quest for an absolute moral ground could be seen as a desire to abandon norms of any kind. This is not the case, however. Rawls takes issue with the "absolute" kind of norm or foundation, one that pretends it can function like a common ground for adjudicating moral claims. Refusing to enter the domain of "adjudicating moral claims," Rawls' theory of liberalism ensures that moral claims can be raised in a free and equal context. The question is whether any moral and religious worldviews can meet the basic threshold of free and equal reciprocity, a threshold of reasonableness (which Rawls says many religious worldviews can do).

If there is no universal foundation for liberalism, does Rawls embrace irrational relativism? In describing liberalism according to the canons of practical reason, does Rawls endanger rationality itself? Does he license each citizen to construct her own unique rationality, at the expense of others? Is the reality that political liberalism can do "without the concept of truth" (epigraph above) make Rawls vulnerable to the charge of pluralistic relativism, the war of all concepts and norms against all others, the war of endless incommensurability? Critics like Patrick Deneen would interrogate Rawlsian liberalism according to this charge.

Political constructivism, as outlined in his major work Political Liberalism, embodies a political theory that mirrors the social practices of the community for which it provides rule of law, without implying that such rule of law must entail metaphysical or religious justification. The construct of a constitutional democracy involves no final, objective, or metaphysical ground. Its social glue is practical, not metaphysical or religious. This contrast between the practical and the metaphysical, while explicit in Rawls, usually is not so explicit in constitutions, court rulings, or other legal documents (it may be described in the language of separation of church and state, or social differentiation of institutions or Lä̈itiê), must nevertheless be clear to citizens. In what way?

For Rawls, the political conception of justice and social cooperation, enforced by the liberal state, does not ignore metaphysical and religious foundations, but rather delegates them to individual choice. It remains neutral in such matters, so far as is possible, since that is the reasonable relationship for a constitutional regime to have with a pluralistic citizenry. The scope of a

9 For a more detailed engagement of these terms, see Charles Taylor (2007) and Steve Bruce (2011). 
liberal democracy's theory of justice, it could be properly argued, remains purposefully self-limited: "political constructivism has been limited to the political values that characterize the domain of the political; it is not proposed as an account of moral values generally" (Rawls 1995, 125). And yet, Rawls does not ask liberal theory to construct a doctrine of justice in a timeless vacuum; quite the opposite. He states society is a fair system of cooperation between free and equal citizens; in this context, constructivism can be the "focus of an overlapping consensus" since so many individuals elect to "give the political conception a metaphysical foundation as part of their own comprehensive doctrine" (Rawls 1995, 126).

Why? It is the purpose of liberalism to defer to individual choice and to allow that individual liberty to flourish with the context of the community (it is form of social contractarianism) so that citizens are free to adopt whatever metaphysical foundations they like, and from those foundations, they can find good reason to justify liberal democracy. The way in which this may occur is called overlapping consensus, and herein lies my point of departure for a hermeneutics of dialogue.

\section{Overlapping Consensus: The Hermeneutics of Public Dialogue}

This picture of Rawls' liberal polity explicitly refuses to grant to public reason a fundamental matrix or moral presupposition that unites all citizens or voices. He is quick to respond to religiously minded objectors who may want personally to utilize a form of natural law or theological foundation. Rawls would have no problem with this method, as long as it is not asserted over the whole citizenry. He reminds us that liberalism does not "criticise religious, philosophical, or metaphysical accounts of the truth of moral judgments and of their validity" (Rawls 1995, 127). Each citizen is given the courtesy or liberty to adopt (or not adopt) a particular moral truth or norm. And yet, religious believers of any kind must become self-aware enough to realize that if they insist on their own particular religious worldview for all, it must be seen by other citizens as their "simply insisting on their own beliefs. This is due to the fact that, while people can recognize everyone else's comprehensive views as reasonable, an individual cannot recognize them all as true, and there is no shared public basis to distinguish the true beliefs from the false" (Rawls 1995, 128). Pluralism resides without an objective foundation: that is, liberalism cannot and will not guarantee common ground on every social issue or moral debate.

Is there, then, no common ground at all? If there is no shared public basis to discriminate true from false beliefs, then how is common ground possible from 

Liberal Citizenship and the Hermeneutics of Public Dialogue: A Rawlsian Perspective the point of view of practical reason in particular? Rawls suggests that there may be a single node of overlap, a point of convergence among competing comprehensive doctrines, and it is political liberalism's conception of justice. The public, according to a purely political conception of justice, consists of nothing more than a pragmatic principle: that fair cooperation between free and equal citizens rule all citizens equally and without exception. Rawls calls the path to practical commonality the principle of overlapping consensus, a pragmatic (not metaphysical) form of coexistence that sees agreement as a token of reasonable pluralism.

Consensus is arrived at by people with very different moral and religious and political commitments, and who sign on to the policy from within their differing points of view, and therefore on possibly very different grounds from each other. Overlapping consensus contrasts with the idea that when one converges on a policy, one must always do so for the same reason or theoretical justification. Rawls would agree that there is no such thing as a "disinterested spectator" or a perspective "from nowhere."10 Hence, he advocates for philosophical framework of embedded, motivated, and embodied subjects whose affections, concerns, and ultimately, practices, reflect the values and moral codes they pursue. We should reject the intuition that Kant took as central: that we all begin with some common principle or basic set of ideas, from which we in time work out and ramify in many different ways. Rawls challenges the version of morality that "starts thin" and "thickens with age," echoing Michael Walzer's well-known thesis, which states that morality is thick from the beginning, culturally integrated, and bound up with practical reason (Walzer 1994).

Framed in light of practical reason, the logic of political liberalism is prosaic and banal, in the sense that it permits each individual to adopt a tradition or worldview that inspires, motivates, and satisfies the inclinations of the individual's deepest spiritual pursuits. Inspiring the soul is not liberalism's job description, though I can see how liberalism may want to encourage certain virtues such as respect for freedom and dignity for all. It may even encourage intense feelings of disapproval, even disgust, to be directed at anti-liberal doctrines like racism or religious bigotry. ${ }^{11}$ Indeed, liberalism, especially as it is formulated in the idiom of a Rawlsian theory justice as free and equal reciprocity, the wars of religion that ravaged Europe after the Reformation

10 Rawls writes, "Thus in contrast wo what Nagel calls 'the impersonal point of view,' constructivism both moral and political says that the objective point of view must always be from somewhere." Rawls $(1995,116)$.

11 For more on this point, see the able book by Martha Nussbaum (2013). 
constitute the proximate cause of the emergence of a liberal state that protects freedom of conscience. ${ }^{12}$ With the struggle of religious authoritarianism borne in mind, all citizens are asked in a liberal paradigm to reconcile themselves with pluralism, rather than try to overcome it, precisely because it protects the integrity of the citizenry's autonomy to choose any worldview to which a citizen should like to subscribe.

\section{A Hermeneutic Strategy}

How can overlapping consensus, though, be harnessed as a concrete strategy for dialogue? As a strategy for public dialogue, overlapping consensus opens up the genuine possibility of dialogue among a citizenry in the public square, and it does so (ideally) in a manner that facilitates agreement and cooperation. It can, if applied intentionally, locate explicit points of policy overlap between religious, quasi-religious, and non-religious citizens. The intentional focus on overlap fosters a "consensus" and a bond that can create real solidarity, if not in theory, at least in practice. This does not yield forth a dictatorship of relativism, but instead focuses on practical consensus which place metaphysics and religious rational between brackets. ${ }^{13}$ What does consensus look like in this public setting? To address the concrete application of overlapping consensus, I am extending Rawls beyond the letter of Political Liberalism, by asking specifically what kind of hermeneutic or mode of interpersonal speech that overlapping consensus can offer as measure of redress in a polarized climate.

Political liberalism, it should be observed as a caveat, can meet the challenges of only so much agonism and difference. As Rawls notes, some citizens are in point of fact illiberal, abdicating their civic responsibility of seeing others as free and equal. He writes, "Those who reject constitutional democracy with its criterion of reciprocity will of course reject the very idea of public reason. ... Political liberalism does not engage those who think this way" (Rawls 1995,

12 Recent works reinterpret the religious wars after the Reformation as a "myth or religious violence" because such wars were simply incapable if using the terminology of "religion." That term came about later in the early modern period, and was only at that time posited against, as a binary opposite, the category of the secular. From my point of view, I interpret Rawls as indicating that theology or comprehensive doctrine to be at fault, at least in large part, for the outbreak of war(s). The wars, to be clear, were still motivated by theology, even if the semantics of the terminology of religious war was yet to be settled, and even if economic and political factors also contributed to the religious wars. For one example of this revisionist history, which make several compelling points, see William Cavanaugh (2009).

13 For more on the polemically charged term dictatorship of relativism, employed by some conservative Christians, see Jeffrey Stout (2007). I do not think that practical consensus can enjoy a unity that is completely void of metaphysical or religious unity too, for moral norms or metaphysical quests are impossible to avoid, however minimal they be in content. For more on this, see Rivera (2016). 

Liberal Citizenship and the Hermeneutics of Public Dialogue: A Rawlsian Perspective 442). I tend to concur. While we may not discover reasons that all can accept in public dialogue, we may nevertheless attempt to find common ground, but we can only pursue that goal together, as citizens who treat each other with mutual respect and trust. Assuming a level of reciprocity, how do those who show little overlap on the surface of things speak to each other? While many who identify with "left" or "right," or even "liberal" or "conservative," may well insist that (at some point) there is not utility in dialogue at all. How can I carry out a conversation, not least, promote civic friendship, with individuals from whom I diverge from so radically? What intentional hermeneutical strategy may we employ in this fraught political climate? The urgent challenge lies in precisely the profound difficulty of civic friendship between individuals and groups that occupy different ends of the political spectrum.

Overlapping consensus, as one important technical term in the Rawlsian lexicon, highlights that many individual citizens use their comprehensive doctrines to agree on political liberalism, as the node or focus of an overlap. Once political liberalism is justified according to one's moral norm (e.g., Christian, Muslim, Hindu, Humanist, etc.), how do a diverse group of citizens overlap in other, more particular areas of public concern, say on issues of public policy? I propose a four-way dialogue format that may explore such a hermeneutical strategy.

While there is no numerical restraint, we can imagine there are initially two parties involved in most ordinary dialogues about social issues. To keep the example manageable, imagine two citizens, one religious and the other atheist, who decide to discuss social entitlements for the poor. The two discussants, no doubt, occupy very different moral imaginaries that justify their stand on public policy issues according to very different, perhaps incommensurable, comprehensive doctrines. Imagine that by happenstance, or design, that they begin a conversation about poverty. How may they proceed?

James Bohman and Henry Richardson recently have advocated that these two discussants exercise caution in this context about civil behavior. They suggest two approaches to avoid: (i) ad hominem hypocrisy, in which one hurls ideological attacks at her interlocutor, say a biblical passage that condemns social entitlements for the poor (to return to our example above), even though she knows the interlocutor does not accept the Bible as a legitimate normative source for navigating moral debate; and (ii) the opposite extreme, cognitive apartheid, in which two citizens, again a Christian and an atheist, avoid talking about their fundamental metaphysical assumptions altogether, as if they could avoid their most basic moral convictions when talking about 
poverty, social justice, and government assistance programs (Bohman and Richardson 2009).

These are helpful precautionary measures or guardrails, what we may call strategies of forbearance we may put into play when confronted with pluralism, say when a Christian and an atheist talk about public policy that bears on poverty, homelessness, and higher taxes on the wealthy. ${ }^{14}$ They indicate clear boundaries not to be exceeded, what we should "not do," whereas, in contrast, the hermeneutic of overlapping consensus, as I conceive of it, indicates a blueprint for what we "can do," that is, how we can talk in a manner that builds two-way bridges of civic friendship.

How is friendship cultivated? We can overlap concerning the issue of social entitlements that may address poverty, even if we do so for different reasons. Richard Rorty, a self-avowed secularist, says he hopes 'pie-in-the-sky religion withers away' because there are too many Jerry Falwells and Joseph Ratzingers (these are his examples). He goes on to say that he "wholeheartedly believes religious people should trim their utterances to suit my utilitarian views" (Rorty 2003, 144). In a more sober moment, he retracts his own fearful and suspicious attitude, even if it is not always unjustified. He admits that if a religious citizen employs Psalm 72 as a reason for helping the poor and universalizing healthcare, and he appeals to a passage from John Stuart Mill's On Liberty on behalf of universal healthcare, then it follows for him that he sees ultimately no difference in approach: both he and the Christian are relying on an authoritative canon that is rooted in a particular tradition (mostly incommensurable to each other), in order to find points of policy overlap concerning urgent social issues.

Finding a way to overlap like the above example suggests more than agreement for the sake of agreement. It can deflate differences, and it can deflate the cultural divide between not just Christians and secularists but between other polarities. Rawls himself encourages his readers to frame political liberalism within the larger hope of a "social union of social unions," a difficult and obscure expression that appears to reimagine public life according to civic friendship, whereby dominate groups attempt to inhabit a co-constructed utopia, within which the citizenry form bonds of trust and reciprocity even if many groups do not share sacred texts, religious institutions, and authorities (Rawls 1995, 322). Deflating differences can, if the circumstances are right,

\footnotetext{
14 I qualify the scenario here by the caveat that many religious adherents may also be atheists and that many theists may not be religious. I fully admit that the dichotomy between a Christian and an atheist does not do justice to the complexity of the religious landscape in western culture. I use it here only as a heuristic device that represents only one such dialogue that could take place.
} 
set into operation a ripple effect, enlarging our social union and our loyalties beyond the borders of immediate ethnic and religious ties.

In other words, most dialogues involve more than two parties. We can imagine, for the sake of analysis, that overlapping consensus can foster a four-way dialogue. In any exchange, like the one on poverty and universal healthcare, there are four parties involved, though located at differing degrees of friendship and acquaintance. Two parties are directly involved, the Christian and the atheist (parties 1 and 2). The two indirect parties represent our respective social circles, say, various colleagues and friends we have the privilege of associating with (parties 3 and 4). In this model of four-way dialogue, assumptions are challenged on both sides, Christian on the one hand, and secular humanist, on the other. The Christian can go back and discuss how atheists are not secretly conniving to rid the public square of religious voices or to eliminate the churches and parishes from having a seat at the table of public policy. There is no conspiracy (at least not systemic) that liberal secularists want to advance an anti-Christian agenda. The atheist, upon returning to the social circle she occupies, can talk about how the spiritually minded, practicing Christians (most of them) are not otherworldly or socially indifferent, or worse, beholden to theocratic inclinations, but genuinely concerned about the welfare of all people.

In this four-way dialogue, we can recognize over time (with regular dialogue) that all citizens consist of multiple dimensions and features, and we can find ways to overcome the specter of identity politics that tends to single out one chief feature as "the" only way to describe my personal identity. We can overlap with others in a variety of lifeworlds. I am a father, a brother, a son, an American expat living in Europe, an avid fan of baseball and classical music. I am made up of a bundle of features and habits. While my religious identity may serve my deepest convictions, it does not have wholly define me. Nor does it have to occlude the evolution of my personal narrative, and how my personal narrative can overlap with the varied features and habits of other subjects in the broader citizenry.

\section{Conclusion}

In this essay, I have been sketching two related socio-political phenomena: the narrative of identity politics that appears to overwhelm liberal regimes, and the counter-narrative of liberal dialogue that places emphasis on a hermeneutical framework of civic friendship, to deflate identity politics and partisan rivalry. Such dialogue, we also noted, does not take place in a 
vacuum, but in a pluralistic context, one protected by liberalism's neutrality in matters of religion, ethics, and moral norms.

The result of liberalism's vision of autonomy is a diversity of viewpoints, some religious and some not, and many (not all) may be incommensurable or incompatible with each other on many chief moral and metaphysical claims (each with their own authorities, texts, and traditions). How may commonality be cultivated, if at all, in this fraught pluralism? Rawlsian overlapping consensus can be extended, as I have done in the final section above, to consider how individual citizens can negotiate the pluralism without giving up their particularity and morally thick lifeworld (whether that is Christian, Muslim, humanist, etc.). Liberalism, as a political order, need not be understood as a theory of how may best "leave each alone" as isolated, disembedded atoms (pace Patrick Deneen above) but can foster dialogue not only among individuals but also among larger groups, a hermeneutical dynamic with a ripple effect I described as a four-way dialogue.

\section{References}

Bivins, Jason. 2008. Religion of Fear: The Politics of Horror in Conservative Evangelicalism. Oxford, UK: Oxford University Press.

Bohman, James and Henry S. Richardson. 2009. "Liberalism, Deliberative Democracy, and 'Reasons that All Can Accept,"' Journal of Political Philosophy 17 (3): 253-74.

Bruce, Steve. 2011. Seculariztion: In Defence of an Unfashionable Theory. Oxford, UK: Oxford University Press.

Cavanaugh, William. 2009. The Myth of Religious Violence: Secular Ideology and the Roots of Modern Conflict. Oxford: Oxford University Press.

Connolly, William. 2005. Pluralism. Durham, NC: Duke University Press.

Dalferth, Ingolf, 2010. "Post-secular Society: Christianity and the Dialectics of the Secular," Journal of the American Academy of Religion, 78 (2): 317-45.

Deneen, Peter. 2018. Why Liberalism Failed. New Haven, CT: Yale University Press.

Dworkin, Ronald. 2008. Is Democracy Possible Here? Principles for a New Political Debate. Princeton, NJ: Princeton University Press. 1986. Law's Empire. Cambridge, MA: Harvard University Press.

Ferrara, Alessandro. 2013. The Democratic Horizon: Hyperpluralism and the Renewal of Political Liberalism. Cambridge, UK: Cambridge University Press.

Habermas, Jürgen, 2012. The Crisis of the European Union: A Response. trans. Ciaran Cronin. Cambridge, UK: Polity Press.

http://www.people-press.org/2016/06/22/partisanship-and-political-animosity-in-2016/[accessed April 20, 2019].

Iyengar, Shanto, Gaurav Sood, and Yphtach Lelkes. 2012. "Affect, Not Ideology: A Social Identity Perspective on Polarization," The Public Opinion Quarterly, 76 (3): 417-18. 
Laborde, Cécile 2017. Liberalism's Religion. Cambridge, MA: Harvard University Press.

Levitsky Steven and Daniel Ziblatt. 2018. How Democracies Die. New York: Penguin Random House.

Manent, Pierre. 2015. Beyond Radical Secularism: How France and the Christian West should Respond to the Islamic Challenge, trans. Ralph C. Hancock. South Bend, IN: St. Augustine's Press.

1996. Intellectual History of Liberalism. trans. Rebecca Balinski. Princeton, NJ: Princeton University Press.

McNamara, Kathleen R. 2015. Everyday Europe: Constructing Authority in the European Union. Oxford: Oxford University Press.

Nussbaum, Martha, 2011. "Perfectionist Liberalism and Political Liberalism," Philosophy and Public Affairs 39 (1): 3-45.

. 2013. Political Emotions: Why Love Matters for Justice. Cambridge, MA: Harvard University Press.

. 2013. The New Religious Intolerance: Overcoming the Politics of Fear in an Anxious Age. Cambridge, UK: Harvard University Press.

Rawls, John. 1995. Political Liberalism. Expanded edition. New York: Columbia University Press.

Rivera, Joseph. 2016. "God and Metaphysics in Contemporary Theology: Reframing the Debate," Theological Studies 77 (4): 823-44.

Rorty, Richard. 2003. "Religion in the Public Square: A Reconsideration,” Journal of Religious Ethics 31 (1): 141-49.

Rousseau, Jean-Jacques. 1999. The Social Contract. trans. Christopher Betts. Oxford, UK: Oxford University Press.

Stout, Jeffrey. 2007. "A House Founded on the Sea: Is Democracy a Dictatorship of Relativism?” Common Knowledge 13 (2): 385-403.

Taylor, Charles. 2007. A Secular Age. Cambridge, MA: Harvard University Press.

Walzer, Michael. 1994. Thick and Thin: Moral Argument at Home and Abroad. Notre Dame, IN: University of Notre Dame Press.

Westphal Merold, 2009. Whose Community? Which Interpretation? Philosophical Hermeneutics for the Church. Grand Rapids, MI: Baker Academic. 